\title{
A DEFENSE OF THE "ZONE OF INTERESTS" STANDING TEST
}

Standing tests prevent abuse of the judicial process while providing citizens pursuing good faith claims with access to the courts. ${ }^{1}$ Preventing abuse of the judicial process and ensuring court access are the "prudential" concerns of standing tests. ${ }^{2}$ Because these concerns may take different forms depending on the type of suit before a court, "[t] the various rules of standing applied in the federal courts . . . have been fashioned with specific reference to the status asserted by the party whose standing is challenged and to the type of question he wishes to have adjudicated." 3 Put another way, all standing tests start with Article III's case or controversy requirement-the nonprudential concern of standing-but they "do not necessarily track one another" beyond this constitutional requirement. ${ }^{4}$ In short, prudential standing tests are context-dependent. Thus specific standing tests incorporate

1. See, eg., Gladstone, Realtors v. Village of Bellwood, 441 U.S. 91, 99-100 (1979); Schlesinger v. Reservists Comm. to Stop the War, 418 U.S. 208, 223 (1974). For a list of relevant secondary sources see Albert, Standing to Challenge Administrative Action: An Inadeguate Surrogate for Claim for Relief, 83 YALE L.J. 425, 425 nn.1\&2 (1974).

Tests to determine standing to challenge administrative action in federal courts, such as the zone of interests test, also promote the separation of powers. See; e.g., Flast v. Cohen, 392 U.S. 83, 100-01 (1967); Tax Analysts \& Advocates v. Blumenthal, 566 F.2d 130, 139-40 (D.C. Cir.), cert. denied, 434 U.S. 1086 (1977).

2. Although Article III's standing requirements must be met before a complainant may invoke the judicial power, nonconstitutional limitations on standing are prudential rules of selfrestraint to be applied in appropriate circumstances. See Gladstone, Realtors v. Village of Bellwood, 441 U.S. 91, 99-100, 100 n.6 (1979); Warth v. Seldin, 422 U.S. 490, $498-501$ (1975).

In administrative cases, as well as in other cases, it is often difficult to distinguish the standing requirement from the requirement that the plaintiff state a cause of action. The best explanation of the distinction is found in Warth v. Seldin, id at 500-01. See infra note 109 and accompanying text; see also infra note 78.

3. Flast v. Cohen, 392 U.S. 83, 101 (1968).

4. Association of Data Processing Serv. Orgs. v. Camp, 397 U.S. 150, 152 (1970). The meaning of Article IIIs case or controversy requirement is beyond the scope of this note. For an in-depth analysis of Article IIr's standing requirement see J. RADCuFFE, THE CASE-ORControversy Provision (1978); see also Brilmayer, A Reply, 93 Harv. L. Rev. 1727 (1980); Brilmayer, The Jurisprudence of Article III: Perspectives on the "Case or Controversy" Requirement, 93 HARv. L. REv. 297 (1979); Lebeh, Standing afler Havens Realty: A Critique and an Alternative Framework for Analysis, 1982 DuKE L.J. 1013; Tushnet, The Sociology of Article III: A Response to Professor Brilmayer, 93 HARv. L. REv. 1698 (1980); infra note 136 and accompanying text. 
different nonconstitutional requirements to facilitate consideration of prudential policy concerns in a given context. ${ }^{5}$

The Supreme Court lias not, liowever, provided guidelines for application of specific standing tests. ${ }^{6}$ As a result, lower courts often apply the tests inconsistently. The "zone of interests" test, used to determine standing to cliallenge certain administrative actions, ${ }^{7}$ has caused particular problems smce its inception. ${ }^{8}$ Courts have blindly applied the test, confused the contexts in which it applies, and distorted its method of application, causing several critics to call for the abandonment of the test.

This note defends the zone of interests test. The note first traces the origin and developinent of the test. It then presents the inajor criticisms of the test and the suggested alternatives. Finally, the note responds to these criticisms and suggested alternatives. It concludes that, when properly applied, the zone of interests test effectively limits standing issues to threshold inquiries while preserving the courts'

5. This note analyzes the zone of interests standing test as it has been developed and applied in administrative law; it does not survey all federal standing tests or all administrative law standing tests. For general surveys of federal standing tests see A. BICKEL, THE LEAST Dangerous Branch: The Supreme Court at the Bar of Polmis 1-33, 116-25 (1962); L. JAFFe, JUdiCial CONTROL OF ADMINISTRATIVE ACTION 459-545 (1965); J. NOWAK, R. ROTUNDA \& J.N. Young, HANDBOOK ON CONSTITUTIONAL LAW 69-83 (1978); L. TRIBE, AMERICAN Constitutional LAW 79-114 (1979). For examples of other administrative law standing tests see Havens Realty Corp. v. Coleman, 455 U.S. 363 (1982)("rester" standing); United States v. Richardson, 418 U.S. 166 (1974)(taxpayer standing); Eisenstadt v. Baird, 405 U.S. 438 (1972) (third-party standing); Flast v. Colen, 392 U.S. 83 (1968) (taxpayer standing).

6. In Association of Data Processing Serv. Orgs. v. Camp, the Court warned that "[g]eneralizations about standing to sue are largely worthless as such" 397 U.S. at 151. More recently, the Court stated that:

"standing" is not a term used for its precision. As it is most commonly understood, standing embraces both constitutional and prudential limitations on a federal court's exercise of jurisdiction. So used, it normally measures the quality of the interest asserted by a private plaintifin in obtaining resolution of a particular dispute through the authority of a court. As a threshold inquiry, we have required the plaintiff to show "some threatened or actual injury resulting from the putatively illegal action." ... Further generalization is hazardous.

Graddick v. Newman, 453 U.S. 928, 938 (1981) (citations omitted).

7. The zone of intetests test was introduced in Data Processing, 397 U.S. at 152.

8. The Supreme Court deserves some of the blane for the confusion. Since introducing the test in 1970, the Court has provided little guidance on its application; it has applied the test just threa times since 1970. See Boston Stock Exch. v. State Tax Comm'n, 429 U.S. 318, 320-21 n.3 (1977); Investment Co. Inst. v. Camp, 401 U.S. 617, 620 (1971); Arnold Tours, Inc. v. Camp, 400 U.S. 45 (1970) (per curiam). The Court has mentioned the test at least seven additional times. See Valley Forge Christian College v. Americans Umited For Separation of Church \& State, Inc., 454 U.S. 464, $473-75$ (1982); Gladstone, Realtors v. Village of Bellwood, 441 U.S. 91, 100 n.6 (1979); Singleton v. Wulf, 428 U.S. 106 (1976); Simon v. Eastern Ky. Welfare Rights Org., 426 U.S. 26, 39 n.19 (1976); United States v. Richardson, 418 U.S. 167, 176 n.9 (1974); United States v. Students Challenging Regulatory Agency Procedures, 412 U.S. 669, 686 n.13 (1973); Sierra Club v. Morton, 405 U.S. 727, 733 (1972); see also Warth v. Seldin, 422 U.S. 490, 500-01 (1975). 
ability to prevent abuse of the judicial process and promote the separation of powers.

\section{ORigin ANd Development of the Zone of INTERests Test}

A. Origin.

By introducing the zone of interests test in 1970, the Supreme Court contmued a trend hiberalizing standing requirements for socalled "competitors' suits," in which complainants challenge agency actions that allegedly injure competitors' ability to coinpete. 9 Before 1968, courts used a "legal interest" test to decide the standing of a party challenging agency action. Under this test, a complainant could not invoke the judicial power to protect an interest or right "unless the right invaded [by agency action was] a legal right, - one of property, one arising out of contract, one protected against tortious invasion, or one founded on a statute which confcrs a privilege."10 Since competitive busimess interests are not interests of property, contract, or tort, coinpetitors had to show that their interests were, in fact, "founded on a statute."11 Accordingly, courts applying the legal interest test often en-

9. See, eg. , K. Davis, Administrative Law Treatise \$ 22.00-5, at 725 (Supp. 1970); Sedler, Standing and the Burger Court: An Analysis and Some Proposals for Legislative Reform, 30 RUTGERS L. REV. 863, 863-69 (1977).

The phrase "competitor's suit" was used in Data Processing to describe actions challenging administrative action alleged to have caused competitive economic injury. 397 U.S. at 152. Use of the phrase in this note assumes the same meaning.

10. Tennessee Elec. Power Co. v. TVA, 306 U.S. 118, 137-38 (1939).

11. Economic injury resulting from lawful competition was not a judicially protectable interest at common law. See 4 Blackstone, Commentaries on the LAwS Of ENGLANd 218 (Tucker ed. 1803) ("it is no nuisance to erect a mill so near mine, as to draw away the custom, unless the miller also intercepts the water. Neither is it a nuisance to set up any trade . . . in neighborhood or rivalship with another.").

In 1882 the Supreme Court incorporated this rule into federal law. See Railroad Co. v. Ellerman, 105 U.S. 166 (1881). In Ellerman a wharf owner sought to enjoin a railroad froin building a competing wharf. The Court held that:

The only injury of which [the wharf owner] can be heard in a judicial tribunal to complain is the invasion of some legal or equitable right. If he asserts that the competition of the railroad company damages him, the answer is, that it does not abridge or impair any such right. If he alleges that the railroad company is acting beyond the warrant of the law, the answer is, that a violation of its charter does not of itself injuriously affect any of his rights. The company is not shown to owe him any duty which it has not performed. Id. at 174.

The Court explained its rationale for extending the common law rule to administrative action in Perkins v. Lukens Steel Co., 310 U.S. 113 (1940). First, it acknowledged separation of powers considerations: "[j]udicial restraint of those who administer the Government's purchasing would constitute a break with settled judicial practice and a departure into fields hitherto wisely and happily apportioned by the genius of our pohty to the administration of another branch of Government." Id at 127-28. The Court then presented a more practical consideration:

Courts should not, where Congress has not done so, subject purchasing agencies of Government to the delays necessarily incident to judicial scrutiny at the instance of potential 
gaged in time-consuming statutory analyses to ascertain whether the statute invoked by a coinpetitor actually protected the asserted economic interest. 12

The Supreine Court eased standing requirenents for competitors in 1968. In Hardin v. Kentucky Utilities Co. the Court stated that:

[C]ompetitive injury provided no basis for standing in . . . [previous cases] simply because the statutory and constitutional requirements that the plaintiff sought to enforce were in no way concerned with protecting against competitive injury. In contrast, it has been the rule ... that when the particular statutory provision invoked does reflect a legislative purpose to protect a competitive interest, the injured competitor has standing to require compliance with that provision. ${ }^{13}$

Thus after Hardin a competitor had to show only that a statute reflected a legislative purpose to protect the competitor's interest, a more liberal standing barrier than the legal interest test.

The Court liberalized competitor standing further by introducing the zone of interests test in Association of Data Processing Service Organizations v. Camp ${ }^{14}$ and Barlow v. Collins. ${ }^{15}$ In Data Processing, an association of data processors and a data processing corporation challenged a ruling by the Coinptroller of the Currency permitting national banks to provide data processing services to their customers and to

sellers, which would be contrary to traditional governmental practice and would create a new concept of judicial controversies. A like restraint applied to purchasing by private business would be widely condemned as an intolerable business handicap.

Id at 130 (emphasis added).

For an analysis of when an interest is "founded on a statute," see L. JAFFE, supra note 5, at 501-31.

12. For examples of the Supreme Court denying standing under the legal interests test see Kansas City Power \& Light Co. v. McKay, 225 F.2d 924 (D.C. Cir.), cert. denied, 350 U.S. 884 (1955) (denying standing to utility companies competing with federally funded power programs); Tennessee Elec. Power Co. v. TVA, 306 U.S. 118 (1939) (denying power company standing to enjoin municipalities from receiving grants and loans to start competing business); Alexander Sprunt \& Son v. United States, 281 U.S. 249 (1930) (denying standing to warehouse owners challenging ICC order requiring railroads to remove prejudicial freight rates).

13. 390 U.S. 1, 6 (1968) (citations omitted) (enphasis added). Previous cases that the Court classified as "in no way concerned with protecting against competitive injury," id, were Perkins v. Lukens Steel Co., 310 U.S. 113 (1940); Tennessee Elec. Power Co. v. TVA, 306 U.S. 118 (1939); Alabama Power Co. v. Ickes, 302 U.S. 464 (1938); Railroad Co. v. Ellerman, 105 U.S. 166 (1881). Previous cases reflecting "a legislative purpose to protect a competitive interest" were Chicago v. Atchinson, Topeka \& Santa Fe Ry., 357 U.S. 77 (1958); Alton R.R. v. United States, 315 U.S. 15 (1942); Chicago Junction Case, 264 U.S. 258 (1924); see also supra note 12.

Ten years before Hardin the Court foreshadowed the Hardin-Data Processing liberalization by stating in respouse to the government's assertion that "a party has no right to complain about lawful competition," that 2 competitor's "standing could hardly depend on whether or not it is eventually held that [the challenged action] can lawfully operate." Chicago v. Atchison, Topeka \& Santa Fe Ry., 357 U.S. 77, 83-84 (1958).

14. 397 U.S. 150 (1970).

1j. 397 U.S. 159 (1970). 
other banks. ${ }^{16}$ The complainants claimed that the ruling violated several statutes that protected them from the type of competitive injury the ruling would cause. ${ }^{17}$ In Barlow, tenant farmers receiving funds under the Food and Agriculture Act of $1965^{18}$ made similar allegations of economic mjury. They alleged that a change in statutory interpretation by the Secretary of Agriculture deprived them of funds and bargaining power with merchants in violation of the Food and Agriculture Act. ${ }^{19}$

The lower courts in Data Processing and Barlow demed standing to the complainants; ${ }^{20}$ the Supreme Court reversed. Acknowledging the lower courts' reliance on the legal interest test and the statutory

16. The ruling stated that "[i]ncidental to its banking services, a national bank may make available its data processing equipment or perform data processing services on such equipment for other banks and bank customers." Comptroller's Manual for National Banks \ 3,500 (Oct. 15, 1966), quoted in Data Processing 397 U.S. at 152.

17. One of the statutes rehed upon, 397 U.S. at 155, was the Bank Service Corporation Act, 12 U.S.C. 81864 (1964). It read in pertinent part: "No bank service corporation may engage in any activity other than the performance of bank service for banks." Id.

The complainants also sued under the Administrative Procedure Act (APA). Section 702 states that "a person suffering legal wrong because of agency action, or adversely affected or aggrieved by agency action within the meaning of a relevant statute, is entitled to judicial relief thereof." 5 U.S.C. 8702 (1976).

18. 7 U.S.C. 8 1444(d) (Supp. IV 1968).

The Court explained the change:

The upland cotton program incorporates a 1938 statute, $88(\mathrm{~g})$ of the Soil Conservation and Domestic Allotment Act, as amended, 52 Stat. 35 and 205, 16 U.S.C. $8590 \mathrm{~h}(\mathrm{~g})$, thereby permitting participants in the program to assign payments only "as security for cash or advances to finance making a crop." The regulation of the respondent Secretary of Agriculture in effect until 1966 defined "making a crop" to exclude assignments to secure "the payment of the whole or any part of a cash * * rent for a farm." 20 Fed. Reg. 6512 (1955). Following passage of the 1965 Act, however, and before any payments were made under it, the Secretary deleted the exclusion and amended the regulation expressly to define "making a crop" to include assignments to secure "the payment of cash rent for land used [for planting, cultivating, or harvesting.]" 31 Fed. Reg. 2815 (1966).

Barlow, 397 U.S. at 160-62 (1970) (footnotes omitted).

19. The Act required the Secretary to provide safeguards to protect the interests of tenants. 7 U.S.C. 8 1444(d)(10) (Supp. IV 1964), quoted in Barlow, 397 U.S. at 164.

20. The lower court opinions in Data Processing exemplify the confused state of competitor standing before Data Processing. The district court, for instance, focused on whether the statutes conferred a specific privilege on the data processors. The count held that economic injury owing to competition is not a legal right and that "neither the National Banking Act nor the Administrative Procedures Act are statutes conferring any specific privilege on plaintifis." 279 F. Supp. 675, 678 (D. Minn. 1968), aff'd, 406 F.2d 837 (8th Cir. 1969), rev'd, 397 U.S. 150 (1970).

In contrast, the Court of Appeals for the Fifth Circuit applied the logical nexus standing test that was promnlgated in Flast v. Cohen, 392 U.S. 83 (1968), after the district court decided the case. The court demed standing without considering the APA, and by dismissing reliance on the Bank Service Corporation Act as being "misplaced." 406 F.2d 837, 839, 843 n.12 (5th Cir. 1969), rev'd, 397 U.S. 150 (1970). By applying Flasts" "taxpayer" standing test, the court failed to obey the Supreme Court's instruction that standing tests are context-dependent. See supra notes 3-5 and accompanying text. 
analysis that the test required, ${ }^{21}$ the Court stated in Data Processing that "[ $t]$ he 'legal interest' test goes to the inerits. The question of standing is different." 22 The Court then replaced the legal interest test with the zone of interests test. 23

As outlined in Data Processing, the zone of interests test is a twopronged inquiry. The court must determine: (1) whether the counplainant adquately alleges an injury in fact; ${ }^{24}$ and (2) whether the alleged injury is to an interest arguably within the zone of interests to be protected or regulated by the statute or constitutional guarantee in question.2s By adding the word "arguably" to the prior test, the Court both liberalized standing requirements for competitors and made standing a threshold test rather than a detailed examination of alleged legal interests. ${ }^{26}$

\section{B. Development.}

Although the zone of interests test is readily verbalized, the courts have had inuch difficulty applying it. They encounter two fundamental problems: (1) how to apply the test properly; and (2) when to apply the test.

21. Data Processing was not the first Supreme Court opinion to notice that the legal interest test often confused standing inquiries with the merits. See Chicago v. Atchison, Topeka \& Santa Fe Ry., 357 U.S. 77 (1958).

22. Data Processing, 397 U.S. at 153. The Court rejected the district court's concern over "specifie statutory privileges," holding that the statutes invoked "do not . . . protect a specified group. But their general policy is apparent; and those whose interests are directly affected by . . . interpretation of the [statute] are easily identifiable." Id. at 157.

The Court also specifically rejected three examples of "legal interest" standing that were mentioned in dicta by the court of appeals. The court of appeals stated that a complainant must do more than merely allege unlawful competition to have standing:

[A] plaintiff may challenge alleged illegal competition when as complainant it pursues 1) a legal interest by reason of pubkic charter, 2) a legal interest by reason of statutory protection, or 3) a "public interest" in which Congress has recognized the need for review of administrative action and plaintiff is significantly involved to have standing to represent the pubbic.

Data Processing, 406 F.2d at 842-43. The Supreme Court emphasized its concern for limiting standing tests to threshold inquiries by discarding the first two of the court of appeals' examples, saying its concern for "the existence or nonexistence of a legal interest is a matter quite dirtinct from the problem of standing." Data Processing, 397 U.S. at 153 n.1. The Court also rejected the court of appeals' third example, private attorney general standing, as inapplicable to the present case. Id.

23. Data Processing, 397 U.S. at 153. By implication, the Court also replaced the Hardin test. See supra note 13 and accompanying text.

24. Id. at 152.

25. Id at 153 .

26. The Court emphasized its intent to change competitor standing in Amold Tours, Inc. v. Camp, 400 U.S. 45 (1970) (per curiam) (reversing decision denying standing to travel agents to cnallenge an order of Comptroller of Currency allowing banks to provide travel services). 
1. How to apply the test. The Supreme Court has offered little guidance on how to apply the zone of interests test. Moreover, the Court has itself evidenced confusion when applying the test. ${ }^{27}$ For instance, in the 1971 case Investment Co. Institute v. Camp, an association of investment companies and several imdividual companies challenged a regulation issued by the Comptroller of the Currency that authorized national banks to operate investment funds. ${ }^{28}$ The Supreme Court, relying on Data Processing, granted standing. The Court held that "[t]he injury to the [investment companies] . . . is indistinguishable" from that in Data Processing. ${ }^{29}$ The Court reasoned that:

[W]e concluded [in Data Processing] that Congress had arguably legislated against the competition that the petitioners sought to challenge, and from which flowed their injury. We noted that whether Congress had indeed prohibited such competition was a question for the merits. In the discussion that follows . . . we deal with the inerits of the petitioners' contentions and conclude that Congress did legislate against the competition that the petitioners challenge. There can be no real question, therefore, of the petitioners' standing. . . . .0

Thus the Supreme Court apparently found it simpler to decide the merits than to resolve the threshold question of standing.

The lower courts have generally done a poor job of applying the test. In most cases, the court merely states that the complainant satisfies the test. ${ }^{31}$ In other cases, the court decides the case on another ground

27. Even in Data Processing and Barlow the Court was unclear. In Data Processing, for instance, the Court quoted an extensive lower court analysis of legislative history and then stated that "[w] do not put the issue in [the lower court's] words, for they implicate the inerits. We do think, however, that [the statute] arguably brings a competitor within the zone of interests protected by it." 397 U.S. at 156. In Barlow, the Court held that the coinplainants were "clearly within the zone of interests protected by the [statute]" because "[i]mplicit in the statutory provisions and their legislative history is a congressional intent that the Secretary protect [their] interests . . . ." 397 U.S. at 164.

28. The regulation authorized national banks "to invest funds held in the capacity of managing agent in a collective investment account, 12 C.F.R. \$ 9.18(a)(3) .... [and] allowed the Comptroller to approve collective investment of such funds in manners other than those expressly provided by Regulation 9, 12 C.F.R. \& 9.18(c)(5)." Investment Co. Inst. v. Camp, 274 F. Supp. 624, 628 (D.D.C. 1967) (footnotes omitted), rev'd on other grounds sub nom National Assoc. of Sec. Dealers v. SEC, 420 F.2d 83 (1969) (per curiam), rev'd in part, vacated in part, 401 U.S. 617 (1971).

29. 401 U.S. at 620 .

30. Id. at 620-21.

31. See, eg., Wilmington United Neighborlloods v. HEW, 615 F.2d 112, 117 (3d Cir. 1980), cert. denied, 449 U.S. 827 (1981); Hollingstorth v. Harris, 608 F.2d 1026, 1028 (5th Cir. 1979); United States v. Gurney, 558 F.2d 1202, 1206 (5th Cir. 1977), cert. denied, 434 U.S. 1062 (1978); Shannon v. HUD, 436 F.2d 809, 817 (3d Cir. 1970); Tucker v. Hardin, 430 F.2d 737 (lst Cir. 1970); Alschuler v. HUD, 515 F. Supp. 1212, 1228 (N.D. Ill. 1981), affd, 686 F.2d 472 (7th Cir. 1982). 
even though the zone of interests test clearly applies. ${ }^{32}$ Still other courts apply the test by examining "objectives and obvious purposes," 33 by considering only the allegations of the complaint, ${ }^{34}$ or by deciding whether it "Inay be reasonably argued" that the asserted interests are protected. ${ }^{35}$

2. When to apply the test. The courts are also confused about when the test applies. The Supreine Court has used the test in just two contexts: ${ }^{36}$ competitor suits and challenges to agency actions that cause " 'aesthetic, conservational, and recreational" injuries ("noneconomic" suits)..$^{37}$ Owing to the Court's intention to keep standing tests context dependent, ${ }^{38}$ applying the zone of interests test in con-

32. See, eg., Richland Park Homeowners Ass'n v. Pierce, 671 F.2d 935, 941 n.3 (5th Cir. 1982); Shifiler v. Schlesinger, 548 F.2d 96, 103 (3d Cir. 1977); Port of N.Y. Auth. v. United States, 451 F.2d 783, 785 n.4 (2d Cir. 1971).

33. Dialysis Center, Ltd. v. Schweiker, 657 F.2d 135, 138 (7th Cir. 1981).

34. Nash v. California, 613 F.2d 10, 14 (2d Cir. 1980).

35. National State Bank v. Smith, 591 F.2d 223, 233 (3d Cir. 1979) (emphasis added).

36. This note focuses on cases in which a statute creates the plaintiffs cause of action. The wording of the test, however, anentions constitutional guarantees. See supro note 25 and accompanying text. The courts remain relatively inactive in cases involving "constitutional guarantecs." While explaining how the zone of interests test applies to noneconomic interests, the Data Processing Court stated that "[a] person or a family may have a spiritual stake in First Amendment values sufficient to give standing to raise issues concerning the Establishment Clause and the Free Exercise Clause." 397 U.S. at 154. In Boston Stock Exchange v. State Tax Comm'n, the Court used the zone of interests test while examining a complainant's standing under the Commerce Clause. 429 U.S. 318, $320-21$ n.3 (1977).

The rationale for applying the test to both spiritual and competitive business interests is the same when complainants invoke a constitutioual guarantee as when they invoke a statute; neither interest is legally protectable absent written law. See infra notes 125-29 and accompanying text. The Supreme Court, however, appears unconcerned with the courts' failure to apply the test in constitutioual cases. In fact, several recent phrasings of the test by the Court do not even mention constitutioual guarantees. See Gladstone, Realtors v. Village of Bellwood, 441 U.S. 91,100 n.6 (1979); Simon v. Eastern Ky. Welfare Rights Org., 426 U.S. 26, 39 n.19 (1976). But see Valley Forge Christian College v. Americans United for Separation of Church \& State, Inc., 454 U.S. 464, 473-76 (1982).

37. After developing the second prong of its competitor standing test, the Court stated that the asserted "interest. . . may reflect "aesthetic, conservational, and recreational' as well as economic values. We mention these noneconomic values to emphasize that standing may stem from them as well as froin . . . economic imjury . . . Data Processing, 397 U.S. at 154. In other words, if a complainant adequately alleges harm to a noneconomic interest, standing nust be "founded on a statute." See United States v. Students Challenging Regulatory Agency Procedures, 412 U.S. 669, 686 n.13 (1973).

The Court's treatment of the zone of interests test when noneconomic injuries are alleged has primarily concerned the constitutional prong:

[P]alpable economic injuries have long been recognized as sufficient to lay the basis for standing. . . . Thus, neither Data Processing nor Barlow addressed itself to the question, which has arisen with increasing frequency ...., as to what must be alleged by persons who claim injury of a noneconomic nature to interests that are widely shared.

Sierra Club v. Morton, 405 U.S. 727, 733-34 (1972) (footnote omitted); see also United States v. Students Challenging Regulatory Agency Procedures, 412 U.S. 669 (1973).

38. See supra notes 3-5 and accompanying text. 
texts other than competitor or noneconomic suits may be improper. ${ }^{39}$ Nevertheless, lower courts have applied the test in other contexts, ${ }^{40}$ including cases involving the exclusionary rule, ${ }^{41}$ grand jury oaths, ${ }^{42}$ condemnation proceedings, ${ }^{43}$ and an attorney's contingency fee agreement. ${ }^{44}$ Other courts have applied the test to complainants in civil rights actions, ${ }^{45}$ antitrust cases, ${ }^{46}$ and private suits. ${ }^{47}$ Courts lave

39. Moreover, the courts do not always apply the test in competitor suits. For example, at least five of the federal courts of appeals have limited their inquiry to injury in fact in cases brought by unsuccessful bidders for government contracts. See Airco, Inc. v. Energy Research \& Dev. Admin., 528 F.2d 1294 (7th Cir. 1975); Armstrong \& Armstrong, Inc. v. United States, 514 F.2d 402 (9th Cir. 1975); Hayes Int'l Corp. v. McLucas, 509 F.2d 247 (5th Cir.), cert. denied, 423 U.S. 864 (1975); William F. Wilke, Inc. v. Department of the Army, 485 F.2d 180 (4th Cir. 1973); Merriam v. Kunzig, 476 F.2d 1233 (3d Cir.), cert. denied, 414 U.S. 911 (1973); see also Spencer, White \& Prentis, Inc. v. EPA, 641 F.2d 1061, 1065-66 (2d Cir. 1981). The test used by these courts originated in the Court of Appeals for the District of Columbia Circuit before the Supreme Court introduced the zone of interests test. See Scanwell Laboratories, Inc. v. Shafier, 424 F.2d 859 (D.C. Cir. 1970).

At least one court of appeals applies the zone of interests test in the same context. See Cincinnati Elecs. Corp. v. Kleppe, 509 F.2d 1080, 1083 (6th Cir. 1975). Another court, although deciding standing under the injury in fact test, also applied the zone of interests test. Merriam v. Kunzig, 476 F.2d 1233 (3d Cir.), cert. denied, 414 U.S. 911 (1973). Finally, one court of appeals has reserved judgment on which test to apply. Spencer, White \& Prentis, Inc. v. United States, 641 F.2d 1061, 1065-66 (2d Cir. 1981).

40. See generally Hasl, Standing Revisited -The Aftermath of Data Processing, 18 ST. Louns U.L.J. 12, 22-39 (1973) (examples of early extensions of the test's scope by the lower courts).

Some courts even confuse the test's fundamentals. See, eg., Mountain States Legal Found. v. Costle, 630 F.2d 754, 768 (10th Cir. 1980) (relying on old legal interest test), cert. denied, 450 U.S. 1050 (1981); National Collegiate Athletic Ass'n v. Califano, 622 F.2d 1382, 1386-91 (10th Cir. 1980) (relying on old legal interest test); Independent Meat Packers Ass'n v. Butz, 526 F.2d 228, $236 \mathrm{a.21}$ (8th Cir. 1975) (plaintiffs 'fail to satisfy the 'zone of interests' facet of the constitutional test of standing") (einphasis added), cert. denied, 424 U.S. 966 (1976). Acevedo v. Nassau County, 500 F.2d 1078, 1083-84 (2d Cir. 1974) (applied as constitutional test); Gibson \& Perin Co. v. Cincinnati, 480 F.2d 936, 942 (6th Cir.) (used a geographical zone), cert. denied, 414 U.S. 1068 (1973); Pacific Legal Found. v. Watt, 529 F. Supp. 982, 990-93 (D. Mont. 1981) (considered apart from prudential concerns).

41. United States v. Calandra, 465 F.2d 1218, 1222-23 (6th Cir. 1972).

42. Beacon Journal Publishing Co. v. Unger, 532 F. Supp. 55, 58 (N.D. Ohio 1982).

43. Robinson v. Knebel, 550 F.2d 422, 424-25 (8th Cir. 1977).

44. Smith v. South Side Loan Co., 567 F.2d 306 (5th Cir. 1978).

45. Owens v. Rush, 654 F.2d 1370 (10th Cir. 1981); Taylor v. Jones, 653 F.2d 1193, 1207-08 (8th Cir. 1981); White v. United States Pipe \& Foundry Co., 646 F.2d 203, 205-06 (5th Cir. 1981); Moore v. Tangipahoa Parish School Bd., 625 F.2d 33 (5th Cir. 1980) (per curiam); Ross v. Allen, 515 F. Supp. 972,976 (S.D.N.Y. 1981); McCarther v. Camelot Inn, 513 F. Supp. 343, 347 n.6 (E.D. Ark. 1980).

46. See, eg., Chrysler Corp. v. Fedders Corp., 643 F.2d 1229, 1232-36 (6th Cir.), cert. denied, 454 U.S. 893 (1981); Malamud v. Sinclair Oil Corp., 521 F.2d 1142 (6th Cir. 1975); see also Davis \& Pratt, Civil Procedure, 1982 DET. C.L. REv. 287, 298-300 (Sixth Circuit use of the test in antitrust cases and its subsequent abandonment). The Supreme Court recently acknowledged the use of the zone of interests test in antitrust cases but did not discuss its validity. Blue Shield v. McCready, 102 S. Ct. 2540, 2547 n.12 (1982).

47. See, e.g., Spector v. L.Q. Motor Inns, Inc., 517 F.2d 278, 285-86 (5th Cir. 1975); Herpich v. Wallace, 430 F.2d 792, 805 (5th Cir. 1970). Compare American Postal Workers Union v. In- 
even applied the test to a defendant ${ }^{48}$ and to the government. ${ }^{49}$

\section{The Major Critics of the Zone of Interests Test and Their Proposed Alternatives}

\section{A. Brennan-White.}

In Data Processing and Barlow, Justice Brennan, joined by Justice White, concurred in the result but wrote a separate opinion in which he dissented from the use of the new test. ${ }^{50}$ Justice Brennan found three major faults with the test. First, lie thought that both the language of the test and its method of application were ill-defined.51 Second, Justice Brennan recognized "a disquieting similarity" between the new test and the "legal interest" test's tendency to reach the inerits.52 Third, he argued that even if the test does not reach the inerits, "it serves only to determine whether the challenged agency action is reviewable . . . in cases where there is no express statutory grant of review to nembers of [the complainant's] class. And, if this is so, it has no place in the determination of standing." 53

Although he has apparently retreated from this position, ${ }^{54}$ Justice Brennan suggested dropping the zone of interests test and requiring only that the complainant ineet the constitutional standing limitationinjury in fact.5s He asserted that "[t]he objectives of the Article III standing requirement are simple: the avoidance of any use of a 'federal court as a forum [for the airing of] generalized grievances about the

dependent Postal Sys. of Am., Inc., 481 F.2d 90 (6th Cir. 1973) (denying standing and refusing to apply the test), cert. dismissed, 415 U.S. 901 (1974) with National Assoc. of Letter Carriers v. Independent Postal Sys. of Am., Inc., 470 F.2d 265, 270-71 (10th Cir. 1972) (granting standing under the test); see also 19 VILL. L. REv. 507 (1974).

48. Hetherton v. Sears, Roebuck \& Co., 652 F.2d 1152, 1155-56 (3d Cir. 1981).

49. United States v. Lewisburg Area School Dist., 539 F.2d 301 (3d Cir. 1976).

50. Data Processing, 397 U.S. at 167 (Brennan, J., concurring \& dissenting).

51. Justice Brennan asked:

What precisely must a plaintiff do to establish that "the interest sought to be protected . . . is arguably within the zone of interests to be protected or regulated by the statute'? How specific an "interest" must be advance? . . . When, too, is his interest "arguably" within the appropriate "zone"? Does a mere allegation that it falls therc suffice?

Id. at 177.

52. Id (emphasis supplied).

53. Id. Justice Brennan warned that the Court's failure to separate standing froun reviewability and the merits would risk uninformed, poorly reasoned decisions that may result in injustice. Id. at 176. At least two courts have expressly included inquiries into reviewability as part of the zone of interests test. Fentron Indus. Inc. v. National Shopmen Pension Fund, 674 F.2d 1300, 1304-05 (9th Cir. 1982); Santex Dairy v. Bergland, 591 F.2d 1063, 1066 (5th Cir. 1979). See generally R. FindLeY \& D. FARBER, ENVIRONMENTAl LAw CASES \& MATERUALS 73-92 (1981) (three out of four cases on "reviewability" only discuss standing).

54. See infra note 84 and accompanying text.

55. 397 U.S. at 171 (emphasis supplied). 
conduct of government ...." "56 Therefore, courts should require only injury in fact because the Court "discarded the notion of any additional requirement when we discussed standing solely in terms of its constitutional content . . . . By requiring a second, nonconstitutional step, the Court cones very close to perpetuating the discredited requirement that the challenged governmental action invaded one of his legal interests." 57

\section{B. Davis.}

In 1977 Professor Davis declared that the Supreme Court's "benign neglect" of the zone of interests test since its introduction had made the test extinct.58 Since 1977, however, the Supreme Court has mentioned the test several times. ${ }^{59}$ Professor Davis responded in 1982, accentuating the widespread confusion surrounding the test: "[s]ometimes [the zone of interests test is the law] but most of the time it is not, and a criterion for determining when it is the law is completely absent." $60 \mathrm{He}$ also advised that "[s]omething resembling the zone test may often be sound," 61 but lower courts should not blindly follow the test. ${ }^{62}$

Professor Davis criticizes four aspects of the test. First, he argues that the phrases "to be protected" and "to be regulated" are analytically faulty. ${ }^{63}$ The phrase "to be protected," according to Professor Davis, "ignores the need for continuing common-law protection of some interests," thereby hindering the development of new common law rights; 64 if the courts can only acknowledge rights "to be protected" by statute or constitutional guarantee, they lose their ability to protect common law rights. On the other hand, Professor Davis thinks the phrase "to be regulated" is too restrictive because all parties regulated in fact should have standing. ${ }^{65}$

56. Id

57. Id at 169 .

58. Davis, Standing, 1976, 72 Nw. U.L. REv. 69, 81 (1977). More recently two other legal scholars labeled the test "effectively abandoned by the Court." Spears and Sanford, Standing to Appeal Administrative Decisions in Texas, 33 BAYLOR L. REv. 215, 228 n.100 (1981).

59. See supra note 8.

60. K. DAvis, supra note 9, \& 22.02-11, at 347 (Supp. 1982). See infra notes 124-37 and accompanying text for this note's "criterion."

61. K. DAVIS, supra note 9, \& 22.02-11, at 351 (Supp. 1982).

62. Id at 352 .

63. Id $\$ 22.00-3$, at 711-12 (Supp. 1970).

64. Id at 711. But see infra notes $85-87$ and accompanying text.

65. K. DAVIS, supra note 9, \& 22.00-3, at 711-12 (Supp. 1970). But see infra note 85 . 
Second, Professor Davis criticizes the zone of interests test as being contrary to previous case law. 66 Third, Professor Davis considers the test "cumbersome, inconvenient, and artificial." $67 \mathrm{He}$ observes that inquiring into zones of interest usually requires courts to examine legislative history, which is inappropriate because "standing is a highly practical [question] that calls for quick and clear answers."68

Finally, Professor Davis argues that the zone of interests test is "contrary to the congressional intent" underlying the Administrative Procedure Act (APA). ${ }^{69}$ To establish this point, he examines the legislative history of section 702 of the APA, the section that covers standing to challenge agency actions. ${ }^{70}$ Professor Davis notes that both congressional committees on the judiciary decided that section 702 "confers a right of review upon any person adversely affected in fact by agency action or aggrieved within the ineaning of any statute."71 Next he points out that the words "in fact" were added after "adversely affected" and that the words "by agency action" followed "affected in fact."72 This shows, he argues, that "the words "within the meaning of any statute' [do not] nrodify 'adversely affected.' "73 Therefore, the zone of interests test contravenes the congressional intent underlying in the APA by allowing "within the meaning of any statute" to inodify

66. See K. Davis, supra note 9, 8 22.00-3, at 712-16. The only Supreme Court case Professor Davis discusses is American School of Magnetic Healing v. McAnnulty, 187 U.S. 94 (1902). In that case, a school in the "business of healing diseases and ailments of the human family," id. at 96, challenged a fraud order issued against it by the Postmaster General pursuant to a statute. See id. at 100 n.1. Professor Davis states that "[t]he School's standing was so clear that the Court did not discuss it. Yet . . ., the interest the School was asserting was not within the zone of interests ..., and therefore the School would lack standing." K. DAVIs, supra note 9, at 713. Lower court cases inentioned by Professor Davis include Morton Navigation Co. v. FMC, 405 F.2d 796 (9th Cir. 1968); Webster Groves Trust Co. v. Saxon, 370 F.2d 381 (8th Cir. 1966); and First Nat'l Bank v. Saxon, 352 F.2d 267 (4th Cir. 1965). But see infro notes 88-90 and accompanying text.

67. K. DAVIs, supra note 9, at 716-19.

68. Id. at 716. Professor Davis concludes:

Aside from the awkwardness and inconvenience of applying the Court's test, is not the question of who should have access to a court's processes more likely to be answered satisfactorily if a court is free to decide on the basis of what it deems to be the needs of justice?

Id. at 719.

69. K. DAVIs, supra note 9, at 719-22.

70. See supra note 17.

71. K. DAVIS, supra note 9, at 720 (emphasis added), quoting SENATE COMM. oN tHE JUDiC1ARY, ADMinistrative Procedure ACt: Report on the Judiciary, S. Rep. No. 752, 79th Cong., 1st Sess. 26 (1945), reprinted in Legislative History OF THE ADMINISTRative ProceDURE ACT, S. Doc. No. 248, 79th Cong., 2d Sess. 212 (1946) [hereinafter cited as Legislative History]; House COMm. on THE JUdiciary, ADMinistrative Procedure ACt, H.R. Rep. No. 1980, 79th Cong., 2d Sess. 42 (1946), reprinted in LEOISLATIVE HistorY, supra, at 276.

72. K. DAvis, supra note 9, at 720. (1968).

73. Id; see also Davis, Standing: Taxpayers and Others, 35 U. CHI. L. REv. 601, 619-20 
"adversely affected."74 Not surprisingly, Professor Davis finds the "injury in fact" test preferable to the zone of interests test. ${ }^{75}$

\section{Marquis.}

Professor Marquis criticizes the zone of interests test for requiring trial courts to "examine the fine and shadowy gradations between what is arguably protected and what is actually protected."76 He therefore does not believe that courts should inake separate inquiries into standing, reviewability, and the 1nerits in a given case. According to Professor Marquis, a defendant will usually present the court with the distinct questions of standing, reviewability, and cause of action in a single notion to dismiss under Rule 12(b) of the Federal Rules of Civil Procedure. ${ }^{77} \mathrm{He}$ advocates relnoving the distinctions between standing, reviewability, and cause of action and addressing questions of protected interests in one inquiry. ${ }^{78}$

74. K. DAvis, supra note 9, at 720-21; see also Scanwell Laboratories, Inc. v. Shaffer, 424 F.2d 859 (D.C. Cir. 1970). But see infra notes $92-93$ and accompanying text.

75. K. DAvis, supra note 9, at 726. Professor Davis also suggests an alteration to make the zone of interests inquiry a useful tool:" A person whose legitimate interest is injured in fact should have standing unless congressional intent is discernible that the interest he asserts is not to be protected." Id. (emphasis deleted); see also id. at 352 (Supp. 1982). This alteration is just a verbose method of saying "arguable," but Professor Davis' rephrasing is in accordance with the nethod of application suggested by this note. See infra notes 122-23 and accompanying text.

76. Marquis, The Zone of Interests Component of the Federal Standing Rules: Alive and Well After All?, 4 U. ARK. LITTLE ROcK L.J. 261 (1981).

77. Professor Marquis states that "Rule 12(b) . . . virtually guarantees this by limiting a defendant to a single motion to dismiss assigning all of the grounds for dismissal which he wishes to advance." Id at 285. But cf. FED. R. CIV. P. 12(h)(2) (a defense of failure to state a claim may be made in any pleading permitted, or at the trial on the merits).

78. Professor Marquis' alternative resembles an earlier suggestion. See Albert, supra note 1. Professor Albert argued that "[w] hether seen as a standard of arguable claims or as a preview of the merits, zone of interest standing appears to serve no intelligible function." Id. at 496 . He suggested that:

The proper initial inquiry is into a litigant's legal interest under principles of claim and not merely arguable presence in a zone. In view of familiar procedural motions for testing claims, neither a standard of arguable claims nor preview of protective intent is a helpful substitute for the determination of legal interest at an early and appropriate stage of a lawsuit .... In short, zone of interest standing is not a screen that serves any purpose that is not better served by the requirements of protected legal interest as part of a claim for relief.

Id. at 497.

Professor Marquis also suggests "eliminating any theoretical distinction between the tests applicable in determining the existence of an implied statutory right of action against governmental and against private defendants." Marquis supra note 76 at 286. In other words, Professor Marquis thinks the zone test should apply in contexts other than administrative law. 


\section{A Defense of THE ZONE OF INTERESTS TEST}

\section{A. A Response to the Critics.}

1. Brennan-White. Justice Brennan's opinion in Data Processing and Barlow faulted the zone of interests test for three reasons. The first-that its terms are ill-defined-is a valid criticisin, evidenced by the current confusion in the lower courts. ${ }^{79}$ This problein, however, does not mandate abandonment of the test. If the test is fundamentally sound, definitional problems can be alleviated. ${ }^{80}$

Justice Brennan's second criticism-that the test is too similar to the legal interest test-is less valid. Owing to the nature of the issue involved, the zone of interests test's tendency to reach the merits cannot be eliminated completely. Although the standing inquiry and the analysis of the merits serve different purposes, they address the same basic issue-protection under the statute sued upon. ${ }^{81}$ When a complainant inust sue under a statute to assert a legally protected interest, a standing imquiry must examine this issue if it is to serve its purpose. ${ }^{82}$

Both Justice Brennan and Justice White have apparently rejected their third criticism-that nonconstitutional standing tests are unnecessary; Justice White apphed the zone of interests test in 1977 without questioning its validity. ${ }^{83}$ Similarly, Justice Brennan acknowledged that standing involves nonconstitutional elements: "standing is a question of whether a plaintiff is sufficiently adversary to a defendant to create an Art. III case or controversy, or at least to overcome prudential limitations on federal court jurisdiction . . . ."84

2. Davis. Professor Davis's first criticism of the zone of interests test-that it hinders the courts' ability to protect common law rightsillustrates the confusion that results when courts and scholars ignore

79. See supra notes $36-49$ and accompanying text.

80. See infra notes 110-37 and accompanying text.

81. This characteristic-examining the asserted interest-has been criticized for failing to limit the test's imquiry to the party. In Flast v. Cohen the Court stated that "the fundamental aspect of standing is that it focuses on the party seeking to get his complaint before a federal court and not on the issues he wishes to have adjudicated." 392 U.S. 83, 99 (1967). The Court retreated from this position in Warth v. Seldin: "Although standing in no way depends on the inerits of the plaintiff's contention that particular conduct is illegal, . . . it often turns on the nature and source of the claim asserted." 422 U.S. 490, 500 (1975); see infra note 109 and accompanying text.

82. In such contexts the courts must examine the source of the cause of action-the statuteto prevent abuse of the judicial process and to promote the separation of powers, which are the prudential concerns of administrative law standing, see supra notes 1-2 and accompanying text. Through such examination the courts can determine whether the purposes of the standing tests are fulfilled.

83. Justice White wrote the Boston Stock Exchange opinion discussed supra at note 8.

84. Davis v. Passman, 442 U.S. 228, $239-40$ n.18 (1979) (latter emphasis supplied). 
the context-dependent nature of standing. ${ }^{85}$ The zone of interests test applies only when a complainant inust invoke a statute to protect an injured interest. ${ }^{86}$ Common law rights, however, are legal interests that do not require a statute for judicial protection. Complainants seeking redress for an injury to an interest protected at common law need only adequately allege that interest, and a court will know that a protectable interest is involved. Therefore, the zone of interests test has no effect on the courts' ability to protect common law rights when applied in proper contexts. ${ }^{87}$

85. Professor Davis's first criticism also claimed that a "to be regulated" standard is analytically faulty because any party regulated in fact should have standing. See supra note 65 and accompanying text. This argument has considerable merit. Under the zone of interests test actual regulation should be prima facie evidence of an interest being arguably within the zone of interests, in which case the second prong of the test requires the same finding as the first-injury in fact. But this criticism does not expose a fault in the test. In fact, by including "to be regulated" in the zone test, the Supreme Court virtually assured standing to parties "regulated in fact" for the reason mentioned above. Before the zone of interests test, courts were able to deny standing to such complainants more easily. See supra notes 9-13 and accompanying text.

86. See supra note 36 ; infra notes $124-37$ and accompanying text.

87. Professor Davis's criticism reflects his tendency to iguore the context-dependent nature of standing tests. For exaunple, he criticizes the Supreme Court's failure to use the test in Duke Power Co. v. Carolina Envtl. Study Group, 438 U.S. 59, 79 (1979), or in Bryant v. Yellen, 447 U.S. 352 (1980). In reference to Duke Power, Professor Davis wrote that "the Court has even discussed a two-prong standing test, without mentioning the 'zone' test." K. DAvis, supra note 9, $\$ 22.02-11$, at 347 (Supp. 1982). His criticism fails for two reasons. First, Duke Power's two-prong test concerned Article III standing, it did not address nonconstitutional standing requirements such as the zone of interests test. See 438 U.S. at 80-81. Second, the complainants challenged the constitutionality of an act under the Fifth Amendinent, asserting property interests. Id. at 69. Such interests are legally protected without the protection of written law. See infra notes 132-33 and accompanying text.

In reference to Bryant v. Yellen, Professor Davis accuses the Court of "flagrantly violating the test." K. DAvis, supra note 9, at 348. Bryant, however, involved the standing of parties who were adversely affected by an agency limitation on irrigation and who had intervened in the hitigation. By not applying the zone of interests test in Bryant, the Court apparently refused to extend its scope to "intervenor standing." See generally Hasl, supra note 40, at 29-30, and sources cited therein (discussing the issue of the test's applicability to intervenors). The Court's refusal to apply the test to intervenors accentuates the prudential concerns behind the test. Since the litigation had already commenced, the concerns over abuse of the judicial process and separation of powers were mitigated, and the need for the zone of interests test disappeared.

Professor Davis's interpretation of a third Supreme Court opinion also reflects his failure to acknowledge the context-dependent nature of standing. He interprets Gladstone, Realtors v. Village of Bellwood, 441 U.S. 91 (1979), as "the all-time high water mark of helpfulness" in application of the test. K. DAvIS, supra, note 9 at 347. But the passage he quotes-the plaintiff "must assert his own legal imterests, rather than those of third parties"-did not describe the zone of interests test; the footnote at the end of the passage stated that "[t]here are other nonconstitutional limitations on standing to be applied in appropriate circumstances . . . See, e.g., Simon v. Eastern Kentucky Welfare Rights Org., 426 U.S. 26, 39 n.I9 (1976)," and restated the second prong of the zone of interests test. Gladstone, Realtors v. Village of Bellwood, 441 U.S. $91,100,100$ n.6 (1979). Gladstone merely established that its facts were not an "appropriate circumstance" for the zone of interests test. 
Professor Davis' second criticism-that the test is unintentionally contrary to prior case law-ignores the Supreme Court's intent to use the zone of interests test as a continuation of the liberalizing trend in standing requirements "where statutes are concerned." 88 Rather than including the test in this trend, Professor Davis compares the test with approaches taken in a 1902 Supreme Court case and in several lower court decisions. ${ }^{89}$ The Data Processing opinion, however, expressly recognized and approved the effect that the zone of interests test would have on prior law. ${ }^{90}$

Professor Davis's third criticism-that the test is cumbersome, inconvenient, and artificial-is in one sense accurate; the courts have indeed had trouble applying the test. Sucli criticism, however, does not mandate abandonment of the test. Rather, the primary cause of any cumbersomeness, inconvenience, and artificiality in the apphication of the test is misunderstanding by the courts. Thus, alleviating Professor Davis' third concern merely requires refinement of the test. ${ }^{91}$

Finally, Professor Davis argnes that the test contravenes the APA because section 702 mandates an injury in fact test rather than a nonconstitutional standing test such as the zone of interests. Professor Scott, however, has observed that "[o]ne might expect a change of such dimensions to be commented upon amidst soine controversy in the course of enactment. It comes as a surprise, therefore, to find that the sole support for this somewhat unnatural parsing . . . is a single sentence, buried in the committee reports . . . .92 The Attorney General's statement in the legislative history that APA section 702 reflected existing law supports Professor Scott's position that Congress did not intend a drastic change in standing requirenients. 93

Clearly, Congress did not enact APA section 702 to confer standing on every party adversely affected by agency action. Moreover, the injury in fact test is an unacceptable standing test for contexts in which the zone of interests test apphes. ${ }^{94}$ The injury in fact test fails to incor-

88. Data Processing 397 U.S. at 154. See supra notes 9-26 and accompanying text.

89. See supra note 66.

90. Data Processing, 397 U.S. at 154-55.

91. For this note's refinement see infra notes 110-37 and accompanying text.

92. Scoth, Standing in the Supreme Court-A Functional Analysis, 86 HARV. L. Rev. 645, 659 (1973).

93. Senate Comm. on the Judiciary, Appendix to Attorney Generul's Statement Reoarding Revised Comamtteme Prnt of Octoder 5, 1945, S. Rep. No. 752, 79th Cong, ist Sess. 7 (1945), reprinted in LEGISLATIVE History, supra note 71, at 224, 230. This statement belies Professor Davis's injury in fact alternative since the "legal interest" test was the existing law. See supra notes 10-12 and accompanying text.

94. Notably, Justices Brennan and White seem to have rejected the injury in fact alternative. See supra notes 83-84 and accompanying text. 
porate any prudential considerations of standing. ${ }^{95}$ Without an additional nonconstitutional step, the injury in fact test therefore would preclude courts froin considering prudential concerns ${ }^{96}$ such as separation of powers and abuse of the judicial process. 97

3. Marquis. Professor Marquis' suggestion of combining all inquiries concerning allegedly protected interests is also an unacceptable alternative to the zone of interests test. As the Brennan-White opinion in Data Processing and Barlow warned, a confusion of standing, reviewability, and the merits unnecessarily increases the potential for badly reasoned decisions denying justice. 98 All justiciability doctrines, including standing and reviewability, are complex "rules of self-restraint" that depend on judicial discretion for proper application. 99 Therefore, if doctrines such as standing and reviewability merge, their specific purposes and rationales merge also, weakening distinctions and requiring further dependence on judicial discretion for proper application. ${ }^{100}$ The greater the discretion, the harder it becomes to predict results and to discern a court's reasoning. Additionally, each of these doctrines serves a specific purpose, and to inerge them would imevitably sacrifice these purposes to some degree. ${ }^{101}$

95. Such concerns form the basis of standing tests. See Valley Forge Christian College v. Americans United for Separation of Church \& State, Inc., 454 U.S. 464, $471-72$ (1982); see supra notes 1-2 and accompanying text.

96. Professor Scott contends that nonconstitutional tests are unnecessary and that "injury in fact" should be the sole standing test. Scott, supra note 92 . He makes an economist's argument: lost opportunity costs resulting from litigating trivial or frivolous claims serve the same purpose as any standing inquiry designed to screen complainants for potential abuse of the judicial process.

He also suggests two categories of standing tests: access standing and decision standing. Professor Scott would use access standing to deny use of the judicial process to an entire "class of claims" that meet the minimum constitutional requirements but are insufficient to invoke the judicial power. In contrast, decision standing would examine the proper scope of the judiciary in public policymaking. He concludes, therefore, that, while "labels are not as important as results," id. at 690 , decisional standing should be dealt with by other justiciability doctrines owing to its failure to focus on the complainant's "imterest in the case." Id. at 684. Two cases that seem to contradict this thcory are discussed below. See infra notes 120-28, 134-37 and accompanying text.

97. See supra note 53.

98. The Supreme Court has described justiciability as a "concept of uncertain meaning and scope." Flast v. Cohen, 392 U.S. 83, 95 (1968). The Court went on to explain:

Standing is an aspect of justiciability and, as such, the problem of standing is surrounded by the same complexities and vagaries that inhere in justiciability. Standing lias been called one of "the most amorphous [concepts] in the entire domain of public law." Some of the complexities peculiar to standing problems result because standing "serves, on occasion, as a shorthand expression for all the various elements of justiciability." In addition, there are at work in the standing doctrine the many subtle pressures whicil tend to cause policy considerations to blend imto constitutional limitations.

Id. at $98-99$ (citations omitted).

99. See Data Processing, 397 U.S. at $168-70$ (1970) (Brennan, J. concurring \& dissenting).

100. See id. at 170-74.

101. Id at 176-78. 
B. An Argument for the Zone of Interests Test.

The zone of interests test serves a useful purpose when properly applied. It prevents unwarranted judicial interference with executive branch decisionmaking while allowing private complainants to obtain redress for injuries in cases in whicls Congress "arguably" 102 intended to protect their interests. The decision of the Court of Appeals for the District of Columbia Circuit in Tax Analysts \& Advocates v. Blumenthal ${ }^{103}$ provides an example.

Tax Analysts involved a challenge to certain IRS regulations controlling domestic tax credits for foreign taxes. ${ }^{104}$ The individual plaimtiff, owner of a doinestic oil well, sued the Secretary of the Treasury to enjoin enforcenent of the regulations, alleging that the regulations allowed coinpeting inultinational oil companies larger tax credits than they deserved under the Internal Revenue Code. ${ }^{105}$ The court denied standing because the plaintiff was not arguably within the zone of interests that the tax provision was intended to protect. ${ }^{106}$

If the court had granted the plaintiff standing in Tax Analysts, it would have put itself in the position of reviewing the decisions of the executive branch. Although courts routinely engage in such review, it seems prudent for a court to deny review when Congress did not even arguably intend the statute to protect a given complainant. Although judicious intermeddling might well result in "better law," there is no reason to believe that the courts are in a good position to do the job of the executive branch. In many cases in which the coinplainant could not prove damages but would pass the injury in fact test, and thereby qualify for imjunctive relief, this unwarranted intermeddling is exactly what would happen. As the Supreme Court recognized in Data Processing and in Barlow lowever, when the complainant can arguably assert that Congress intended for the statute to protect his interests, this prudential justification gives way to the judicial duty to redress grievances. 107

Thus, the zone of interests test represents a balancing of prudential concerns grounded in the separation of powers. ${ }^{108}$ As the Court stated in Warth v. Seldin:

102. See supra note 25 and accompanying text.

103. 566 F.2d 130 (D.C. Cir. 1977), cert. denied, 434 U.S. 1086 (1978).

104. Id at 134 .

105. Id at 134-35.

106. Id at $143-44$.

107. See supre note 27.

108. The Cour of Appeals for the District of Columbia Circuit concluded that:

[T] he zone test serves the purpose of allowing courts to define those instances when it believes the exercise of its power at the instigation of a particular party is not congruent with the mandate of the legislative branch in a particular subject area. 
Without such limitations-closely related to Art. III concerns but essentially matters of judicial self-governance-the courts would be called upon to decide abstract questions of wide public significance even though other governmental institutions may be more competent to address the questions .....

... Essentially, the standing question in such cases is whether the constitutional or statutory provision on which the claim rests properly can be understood as granting persons in the plaintiff's position a right to judicial relief. ${ }^{109}$

Thus, as long as the test can be applied with some degree of consistency, it should be retained.

\section{Proper Application of the ZoNe of INTEREsts Test.}

\section{A. How the Test Should be Applied.}

Much of the controversy surrounding the zone of interests test is the result of the courts' failure to apply the test properly. The primary area of confusion is the role of legislative history. ${ }^{110}$ Ideally, because the Supreme Court introduced the test to avoid reaching the merits while deciding standing, only the words of the statute sued on should be examined when applying the test. Realistically, deciding whether an interest is arguably "protected or regulated" requires an understanding of the law's purpose, whicl often requires resort to legislative history. But extensive examination of legislative history defeats the test's intent to keep standing a threshold inquiry. Such detailed analysis only confuses standing with the merits and wastes a court's time. ${ }^{111}$

The approacl to the test used by the Court of Appeals for the District of Columbia Circuit in Tax Analysts strikes the appropriate balance in examining the legislative history. The Tax Analysts court limited its standing inquiry to whether the coinplainant alleged an in-

\footnotetext{
By its choice of language, the Supreme Court has indicated that the zone test is a quite generous standard; on the other hand, the test is obviously meant to serve as a limitation on those who can use the federal courts as a forum for grievances einanating from agency action taken pursuant to a particular statutory mandate. These competing considerations serve to frame the bounds of a court's discretion in applying the zone test. The discretion of a court to deny standing on the basis of the zone standard is not undefined; the zone test limitation is grounded in Congressional action as enbodied in statute.
}

Tax Analysts, 566 F.2d at 140 (footnote omitted); see also supra note 11.

109. 422 U.S. 490,500 (1975) (footnote omitted).

110. See, eg., Copper \& Brass Fabricators Council, Inc. v. Department of the Treasury, 679 F.2d 951, 954 (D.C. Cir. 1982) (Ginsburg, J., concurring in the result); supra note 27.

111. Many courts have nevertheless engaged in such an analysis. See, e.g., Copper \& Brass Fabricators Council, Inc. v. Department of the Treasury, 679 F.2d 951 (D.C. Cir. 1982). 
terest arguably protected by the statutory language alone. ${ }^{112}$ Legislative history became relevant to the court only if it expressed a clear intent to protect or to iguore the asserted interest. ${ }^{113}$ The court chose its approach for three reasons: (1) to avoid prejudgment of the inerits; (2) to simplify the inquiry because of the improbability of the legislative history providing dispositive evidence; and (3) to preclude undermining the "generous nature" of the test. 114

This approach effectively satisfies Professor Davis's concern over the test being "cumbersome, inconvemient, and artificial"11s while retaining flexibility for the court. The approach provides a standardized procedure for comparing a complainant's asserted interest with the statutory language alleged to protect that interest. It also preserves the "generous nature" of the test by accentuating the word "arguably" and by restricting the inquiry to the face of the statute. As the court reasoned, "[t]he 'arguable' language of the zone test thus serves to resolve potential ambiguities in the legislative history [in favor of standing] and obviates the need to consnlt [legislative history] in the same detail as is done when the inerits of the dispute are being resolved." 116

Applying the Tax Analysts approach to that case and to the facts of the Data Processing case illustrates the merit of the approach. In Data Processing, competitors harmed by activities of the national banks sued under a statute providing that "[n]o bank service corporation may engage in any activity other than the performance of bank services . ..."117 The Tax Analysts court supplied its approach to such a case: "if Congress had in general terms legislated against competition in a statute, it is not difficult to find that particular competitive interests, whicl inay not have been mentioned in the legislative history . . . , are 'arguably' within the zone of interests" of the statute. ${ }^{118}$ The data processors would therefore have standing to assert their particular

112. 566 F.2d at 142 . The court also addressed the issue of which statutes are relevant in the inquiry. It decided that the relevant statutory provision is "the [one forming] the basis for the lawsuit" because "the statutory provision at issue in a given case . . . frames the substantive issue which a court will decide. . . Id at 140-41. To consider other provisions would confuse standing inquiries because of Congress' common intent "to accounplish a wide variety of economic and social goals and purposes" in one act; "the possibilities for litigation would . . . be endless." Id. at 141. The court qualified this approach by permitting extension of its inquiry to provisions sharing "an identity of purpose." Id.

113. "[W]e would expect to be informed by the parties if the legislative history contained clear evidence of an intent either to allow the appellant's interests as a basis for standing or to deny standing to a party in this position." Id at 143 n.80.

114. Id. at $141-42$.

115. See supra notes $67-68$ and accompanying text.

116. Tax Analysts, 566 F.2d at 142.

117. Data Processing, 397 U.S. at 155.

118. Tax Analysts, 566 F.2d at 142 (footnote omitted). 
competitive interest because the statute sued on expressed a general intent to legislate against competition. ${ }^{19}$

In contrast, Tax Analysts involved a competitor suing under a statute granting a tax credit for "any income . . . taxes paid or accrued ... to any foreign country. . .."120 The court held that the purpose of the statute was clear on its face, being "to prevent the double taxation of any United States coinpanies operating abroad."121 Accordingly, domestic competitive interests were in no way within the statute's zone of interests because there was no general intent to legislate against competition. ${ }^{122}$ Thus, the test can be readily applied as long as the court confines itself to the statutory language and its arguable implications. ${ }^{123}$

\section{B. When the Test Should be Applied.}

The controversy surrounding the zone of interests test is also partially the result of courts applying it in inappropriate circumstances. Each standing test applies only in certain contexts; ${ }^{124}$ the zone of interests test is no different.

The Supreme Court's opinions provide guidance as to when the test should apply. First, the test applies in coinpetitor suits, when the complainant adequately alleges economic injury caused by agency action, as in Data Processing. ${ }^{125}$ The test also applies to coinplainants alleging noneconounic injury to "aesthetic, conservational, and recreational" interests. 126 Neither competitive economic injuries nor aesthetic, conservational, and recreational interests are legally protected

119. The Supreme Court reached the same result in less convincing words, apparently relying on a lower court opinion that examined the merits. See supra note 27.

120. 26 I.R.C. $\$ 901(\mathrm{~b})(1)(1976)$.

121. Tax Analysts, 566 F.2d at 143.

122. The court also described and rejected a "reverse zone of interests analysis" under which complainants "could argue that they fall within the zone protected by negative implication of the statutory provision." Id. at 144.

123. The Court of Appeals for the District of Columbia Circuit has had trouble following this approach. In 1981 the court examined legislative history and subsequent congressional commentary and stated that it did not believe its inquiry conflicted with the Tax Analysts opinion. Control Data Corp. v. Baldridge, 655 F.2d 283, 294 n.21 (D.C. Cir.), cert. denied, 454 U.S. 881 (1981); see supra note 113. In 1982 the court's short opinion in a competitor's suit focused on legislative history. Copper \& Brass Fabricators Council, Inc. v. Department of the Treasury, 679 F.2d 951 (D.C. Cir. 1982). A concurring opinion questioning whether the court's method of inquiry was appropriate indicates that the court may begin to reemphasize the Tax Analysts approach. Id. at 953-55 (Ginsburg, J., concurring in the result).

124. See supre notes 3-5 and accompanying text.

125. Data Processing, 397 U.S. at 152.

126. See supra note 37. 
rights in the abstract. ${ }^{127}$ Such unprotected interests require a particular written law for legal protection. ${ }^{128}$ The zone of interests test merely ensures that complainants asserting such interests have, at least, an arguable claim to legal protection under the statute on which suit is brought.

Thus, the test should apply in suits against the government in which the complainant unust rely on a statute for legal protection. ${ }^{129}$ In many cases Congress passes vague statutes that create rights unknown at common law. In such cases the zone of interests test serves to circumscribe the use of judicial power to a lesser extent than the legal interests test that it replaced. Conversely, in suits concerning well established rights the test should not apply. In such cases, the rights of the complainant are so well defined that application of the test would be mere a formality.

Many courts, lowever, apply the test in contexts in which it is inappropriate, especially in administrative law cases. ${ }^{130}$ Apparently, these courts assume that "within the ineaning of a relevant statute" refers to the basis of the offending agency action; because all administrative action depends on a statutory grant of authority, they conclude that the test applies to all administrative law cases. This conclusion is erroneous. Standing inquiries examine complainants and their status, ${ }^{131}$ not the basis of the defendant's action. Whether the zone of interests test applies, therefore, depends on whether the complainant must invoke a particular statute to protect its asserted interest.

The cases provide numerous examples of lower courts applying the test in improper contexts. In Robinson $v$. Knebel, for instance, the Court of Appeals for the Eighth Circuit improperly applied the test to

127. See supra notes 36-37.

128. Justice Frankfurter stated this principle succinctly:

A litigant ordinarily has standing to challenge governmental action of a sort that, if taken by 2 private person, would create $a$ right of action cognizable by the courts . . . . Or standing may be based upon an interest created by the Constitution or a statute. But if no counparable common-law right exists and no such constitutional or statutory interest has been created, relief is not available judicially.

Joint Anti-Fascist Refugee Comm. v. McGrath, 341 U.S. 123, 152 (1951) (Frankfurter, J., concurring) (citations omitted) (emphasis added).

129. Several courts have extended the test's scope beyond the application suggested here. See Schiaffo v. Helstoski, 492 F.2d 413, 421 (3d Cir. 1974); In re Grand Jury Proceedings, 450 F.2d 199, 210 n.6 (3d Cir. 1971)(en banc), cert. denied, 408 U.S. 922 (1972). Although the zone of interests test may well be useful in cases involving private defendants, such as antitrust cases, see supra notes 46-47 (authorities cited), consideration of such extension of the test is beyond the scope of this note.

130. See supra notes $40-49$ and accompanying text.

131. See supra note 3 and accoinpanying text. 
landowners challenging the condemnation of their land.132 The complainants asserted a property right protected by common law, eliminating the need to invoke a statute. ${ }^{133}$ The statutes that they sued under served only to force an agency to comply with its terms; the statutes did not provide the sole basis for legal protection of the particular interest asserted.

Committee For Auto Responsibility v. Solomon ${ }^{134}$ exeinplifies another improper extension of the zone of interests test. In Solomon the Court of Appeals for the District of Columbia Circuit required complamants alleging physical health imjuries to satisfy the test. ${ }^{135} \mathrm{Al}-$ though the case could have been dismissed for lack of standing under other tests, ${ }^{136}$ the zone of interests test was invoked even though it did not apply in that context; physical health is a legally protected interest even without a statute. ${ }^{137}$ Again, the complainants in Solomon inerely sued on the statute to establish the impropriety of the agency action, not to establish a legal interest.

\section{Conclusion}

The Supreme Court has warned that "[g]eneralizations about standing . . . are largely worthless as such." 138 Federal courts must therefore regard standing tests as context-dependent threshold inquiries. Failure to do so inerely creates confusion and unpredictability. The current status of the zone of interests test illustrates the results of courts blindly applying specific standing tests.

The confusion and unpredictability surrounding the test can be mitigated if courts adhere to certain fundannental principles. First, it applies only in contexts in which the complainant must rely on statutory law for legal protection of its asserted interest. Second, the test

132. 550 F.2d 422, 424-25 (8th Cir. 1977).

133. See supra note 11 and accompanying text.

134. 603 F.2d 992 (D.C. Cir. 1979).

135. The complainants alleged that an agency's failure to charge commercial parking rates to federal employees caused them health and conservational injury. Id at 997-98.

136. In a recent attempt to clarify distinctions between constitutional and nonconstitutional standing inquiries, the Supreme Court stated that "Art. III requires . . . that the injury "fairly can be traced to the challenged action' and 'is likely to be redressed by a favorable decision." "Valley Forge Christian College v. Americans United For Separation of Church \& State, Inc., 454 U.S. 464, 474 (1982) (citations omitted). Since the injuries, if any, resulting from the incremental increase in air and noise pollution caused by the lower parking rates would not be redressed by a favorable decision, standing could have been denied on this ground-especially given the apparently frivolous nature of the action.

137. See, e.g., Scientists' Inst. for Pub. Information, Inc. v. Atomic Energy Comm'n, 481 F.2d 1079, 1094 (D.C. Cir. 1973); Environmental Defense Fund, Inc. v. Ruckelshaus, 439 F.2d 584, 598 (D.C. Cir. 1971).

138. Data Processing, 397 U.S. at 151; see supra note 6. 
does not require extensive statutory analysis or examination of legislative history. Third, the test should be used to grant standing liberally. ${ }^{139}$ Finally, it is a nonconstitutional test that is irrelevant whenever Congress has expressly granted standing in the statutory language. 140 Kept within these contours, the zone of interests test protects the judiciary from suits brought by complainants Congress never intended to protect in a given statute.

Sanford A. Church

139. The Court does seem to be contricting access to the judicial process, but it is doing so through the constitutional requirement, the first prong of the zone of interests test. See Valley Forge Christian College v. Americans United for Separation of Church \& State, Inc., 454 U.S. 464, $471-76$ (1982).

140. Warth v. Seldin, 422 U.S. 490, 500-01 (1975). Given thet Congress cannot reduce standing below the constitutional requirement, it is interesting thet the Supreme Court apparently has chosen to constrict standing through interpretation of the injury in fact requirement rather than mrougin the zone of interests test. 